\title{
Everett Rogers innovációs elmélete és annak felhasználási lehetőségei az egészségfejlesztésben
}

\author{
The Diffusion of Innovations theory and its relevance to health promotion
}

\author{
Szerző: $\quad$ Csizmadia Péter $₫$ \\ Emberi Erőforrások Minisztériuma
}

Beküldve: 2017. 11. 13.

doi: $10.24365 /$ ef.v58i4.208

\begin{abstract}
Összefoglaló: A cikk célja az innováció diffúziójának Rogers által kidolgozott elméletének bemutatása és használati lehetőségeinek felvillantása a népegészségügyben. Az innováció diffúziója elmélet alkalmazása pozitív változást hozhat az egészségfejlesztésben és a prevencióban, globális és helyi szinten egyaránt. Az elmélet hozzájárulhat az egészségmagatartást befolyásoló tényezők jobb megértéséhez, beleértve az innovációk alkalmazásának feltételeit, ezáltal a teóriának széleskörű alkalmazási lehetőségei lehetnek a népegészségügy területén.

Kulcsszavak: innováció; egészségfejlesztés

Summary: The aim of this paper is to review Rogers' theory of Diffusion of Innovations (Dol) and its possible use in the field of public health. Applying this theory can lead to positive changes in health promotion and disease prevention both at global and local level. This theory can help to better understand determinants of health behaviour, including the prerequisites for innovation, thereby promoting the wide-ranging possibilities of applying this theory in the field of public health.
\end{abstract}

Keywords: innovation; health promotion

A cikk célja az innováció diffúziójának Rogers által kidolgozott elméletének bemutatása és annak használati lehetőségeinek felvillantása a népegészségügyben. Ez az elmélet az egészségfejlesztés területén is eredményesen alkalmazható lenne és tudomásunk szerint nem történt még hazai kísérlet ilyen irányúi hasznosítására. Ebben a cikkben röviden csak az elmélet főbb gondolatait kívánjuk bemutatni, míg egy másik írás feladata lehet egy esettanulmányon keresztül bemutatni a teória népegészségügyben való gyakorlati megvalósítási lehetőségeit. Az innováció diffúziója elmélet alkalmazása pozitív változást hozhat az egészségfejlesztésben és a prevencióban globális és helyi szinten egyaránt, hozzájárulhat az egészségmagatartást befolyásoló tényezők jobb megértéséhez, beleértve az innovációk alkalmazásának feltételeit.
Először röviden áttekintjük az innovációk társadalmi elterjedésével kapcsolatos Everett M. Rogers által kidolgozott általános diffúzióelméletet. Ezután a Rogersi elmélet egyes felvetéseiből kiindulva vizsgáljuk a népegészségügyi innovációk diffúziójának bizonyos jellegzetességeit.

\section{Társadalmi diffúzió ${ }^{1}$}

A társadalomtudományokban régóta jelen lévő kérdés, hogy miképpen terjed el az emberi közösségekben egy új gondolat, eszme, gyakorlat, technológiai újítás. Az elterjedés jelenségeiről a 19. század végén és a 20. század elején a korai elméletalkotók, mint a társadalmi változások kulcsfolyamatairól gondolkodtak. 


\section{Az innováció ${ }^{2}$}

Az innovációval foglalkozó szakirodalmak kiindulópontként az innováció Schumpeter-féle típusaira hivatkoznak a leggyakrabban:

- a fogyasztók körében még nem ismert új javak vagy ezek új minőségének az előállítása (termékinnováció);

- egy új termékhez kapcsolódva új termelési vagy kereskedelmi eljárás alkalmazása (folyamatinnováció);

- új elhelyezési lehetőség, egy értékesítési feladathoz kapcsolódva új piac megnyitása (piaci innováció);

- nyersanyagok vagy félkész áruk új beszerzési forrásainak felkutatása, megszerzése (beszerzési innováció);

- a feladatokhoz jobban illeszkedő új típusú szervezet létrehozása, iparági struktúra átalakítása (szervezeti innováció).

Schumpeter aszerint határolta el az innováció típusait, hogy az újdonság a termékben, a termelési eljárásban, vagy a marketing- és szervezési módszerekben öltött-e testet, léteznek azonban másfajta tipizálások is. A fentiekben felsorolt kategóriák véleményünk szerint a beszerzési innováció kivételével az egészségfejlesztésben is alkalmazhatóak.

\section{A Rogers-féle elmélet ${ }^{1}$}

Rogers a különböző területeken és témákban folytatott kutatások áttekintése után, azok eredményeit összegezve és továbbgondolva, egy általános diffúzióelmélet kidolgozására törekedett. Szintézisében az újítások elterjedésének folyamatát - kommunikációelméleti szakember lévén - alapvetően kommunikációs folyamatnak tekinti. Az adott innovációra vonatkozó, különböző jellegű információk meghatározott csatornákon keresztül, bizonyos idő alatt terjednek el az adott társadalmon belül. A diffúziós folyamat négy alapvető összetevője: maga az innováció, a kommunikációs csatornák, az idő, valamint az adott társadalmi rendszer, amelyben az elterjedési folyamat lezajlik. A szerző sorra veszi az egyes dimenziókat és az azokban szerepet játszó olyan tényezőket, amelyek lényegesen befolyásolják az innováció elterjedésének ütemét.

\subsection{Az adoptálás ${ }^{1}$}

Rogers az innovációt olyan gondolatként, gyakorlatként vagy tárgyként definiálja, amelyet az egyén vagy az alkalmazó csoportok újnak értékelnek. A tapasztalatok szerint az adoptálás ütemét jelentôsen megszabják az adott innováció jellegzetességei, így a népegészségügyi innovációk csak erre a tudományágra jellemző sajátosságokkal rendelkeznek, amelyek meghatározzák és magyarázzák az adoptálásban megfigyelhető eltéréseket. Aszerint, hogy a potenciális adoptálók szempontjából milyen tulajdonságokkal rendelkeznek, az újítások öt fő kategóriába sorolhatók. Ezek közül az első:

- Amelyet relatív előnynek nevez, arra vonatkozik, hogy az adott újítás milyen mértékben jobb, mint a már meglévő eljárás, amit helyettesíthet. Relatív előnyt jelenthet például, ha az innováció adoptálása gazdaságilag, financiálisan kedvezőbb. Kutatások szerint a piaci tényezők az egyik legfontosabb magyarázatát adják annak, hogy egyes innovációk milyen mértékben terjednek el. Hasonlóan fontos szempont lehet, hogy az adoptálás milyen egyéb társadalmi előnyökkel jár együtt. Az eddigi kutatásokból levonható az az általános következtetés, hogy egy újítás potenciális felhasználók számára mutatkozó relatív előnye egyenes arányban van adoptálásának sebességével.

- A következő fogalom a kompatibilitás, amely azt mutatja meg, hogy egy innováció mennyire fér össze a potenciális alkalmazók értékeivel, szükségleteivel és múltbéli tapasztalataival. Egyes innovációk terjedését könnyen megakadályozhatja, ha azok használata ütközik az adott közösség értékeivel vagy szokásaival. Emellett egy innováció elterjedésének mértékét az is komolyan befolyásolhatja, hogy menynyire hasonló valamely, az adott közösségben már meghonosodott formához, gyakorlathoz. Minél nagyobb gondolkodásbeli változásra, illetve minél több új tudás elsajátítására van szükség a befogadáshoz, használathoz, annál kevésbé lesz sikeres és gyors a diffúziós folyamat. Általánosítva tehát elmondható, egy újítás elterjedésének sebessége pozitív kapcsolatban áll a potenciális adoptálók által tapasztalt kompatibilitással.

- A komplexitás annak foka, hogy az adott újítás 
és annak használata mennyire közérthető. Logikusnak tűnik, hogy egy innováció komplexitásának foka és az adoptálás sebessége fordított arányban áll egymással.

- A kipróbálhatóság az elmélet szerint annak mértéke, vagy lehetősége, hogy az adott innováció szélesebb körû alkalmazás előtt milyen kisebb alapokon kísérletezhető ki. Minél több lehetőség nyílik a viszonylag kockázatmentes kipróbálásra, annál gyorsabb ütemű az adoptálás.

- A megfigyelhetőség arra vonatkozik, hogy az újítás eredményei mennyire átláthatóak, nyilvánvalóak. A megfigyelhetőség mértéke és az adoptálás sebessége egymással egyenesen arányos.

Rogers hangsúlyozza, hogy a fenti dimenziók vizsgálatának a potenciális felhasználók szempontjából kell megtörténnie. Hiába tünik ugyanis gazdasági vagy müszaki, esetünkben az egészség szempontjából úgy, hogy egy adott termék vagy eljárás, beavatkozás használata jóval egyszerübb, hatékonyabb, hasznosabb az előző formáknál, ha ez a potenciális adoptálók szubjektív nézőpontjából csöppet sem ilyen egyértelmú.

\subsection{Döntési folyamat ${ }^{3}$}

Az innovációval kapcsolatos döntési folyamat 5 fö lépésből áll, ezek a tudás, a meggyőzés, a döntés, az alkalmazás és a megerősítés.

A tudás akkor jön létre, amikor az egyén értesül az innováció létezéséről és bizonyos fokig megérti a múködését. Ebben a státuszban az egyén által öszszegyújtött információk igyekeznek csökkenteni a bizonytalanságot az ok-okozati összefüggést illetően arra vonatkozóan, hogy az innováció rendelkezik-e azzal a tulajdonsággal, amely képes egy egyéni problémát megoldani.

Ebben a szakaszban az egyén által beszerzett információ általában csökkenti a bizonytalanságot, hogy mennyiben képes segíteni az egyént valamilyen probléma megoldásában az innováció.

Meggyőzésről (vélemény kialakítása) van szó, amikor az egyén pozitív vagy negatív attitűdöt alakít ki az innovációval kapcsolatban.

A döntés akkor megy végbe, amikor egy személy által megvalósított tevékenységek az innováció elfogadásához vagy elutasításához vezetnek. Mindkettônél az egyén az innováció értékeléséhez keres információkat, hogy csökkentse az innováció várható következményei iránti bizonytalanságot, és igyekszik megtudni az innováció előnyeit és hátrányait a saját helyzetével kapcsolatban.

A megvalósítás (implementation) akkor valósul meg, amikor a személy használja az innovációt. Ez a szakasz magában foglalja a nyílt viselkedésváltozást, ami az újdonság használata által történt.

A megerősítés (confirmation) akkor jelentkezik, amikor az egyén a már meghozott innovációval kapcsolatos döntést megerősít, de az még megfordítható, ha ellentmondásos üzeneteket kap a témában. Ezen a ponton az egyén eldöntheti, hogy az innováció használata (vagyis adoptálás) mellett dönt, vagy nem használja (azaz visszautasítja).

A döntési folyamat megértése döntő fontosságú a diffúzió terjedelmének maximalizálása és az innováció elfogadásának mértéke szempontjából. A folyamat fent említett öt fázisát követve egy közegészségügyi kampányt optimálisan, lépésről lépésre meg lehet tervezni.

Egy innovációval kapcsolatos döntési folyamatot jól illusztrálhatunk a dohányzás visszaszorításáért folytatott népegészségügyi erőfeszítések vázlatos bemutatásán keresztül. Az 1950-es évek elején megjelent tudományosan megalapozott kutatások hatására a brit Medical Research Council 1957-ben közleményben tárta a világ elé, hogy a tüdőrák és dohányzás között közvetlen kapcsolat található, azonban korlátozó intézkedéseket nem vezettek be, minden ember magánügyének tekintve a dohányzással kapcsolatos attitüdjét. 1964-ben az Amerikai Egyesült Államok tiszti főorvosa adott hasonló tartalmú riportot. Gyakorlatilag ekkor kezdődött a dohányzás visszaszorításának folyamata, illetve a nem dohányzók védelme a káros hatásokkal szemben. Természetesen elsősorban a dohánygyártók lobbi érdekeinek a hatására társadalmi vita robbant ki a dohányzással kapcsolatban pro és kontra érveket felsorakoztatva. A politika is tartott tőle, hogy a dohányzás korlátozása a választási eredményeket is befolyásolhatja. 1970 áprilisában Nixon elnök aláirta azt a törvényt, amely betiltotta a cigaretta reklámozását a televízióban és a rádióban. Ezek után a vita eldőlt, különböző módszerekkel és aktivitásokkal (dohányzás tiltása különböző területeken, dohánytermékek figyelmeztető feliratokkal való ellátása, dohányzásról való leszokást segítő programok indítása, társadalmi szervezetek bevo- 
nása a szövetségi és állami szint mellé) a dohányzás az Egyesült Államokban jelentősen visszaszorult (természetesen nem egy egyenes vonalú folyamatról van szó, itt csak vázlatosan megemlítettük a főbb vonatkozásokat).

\subsection{Change agent ${ }^{3}$}

Rogers az interperszonális hálózatoknak az innováció elfogadásában meghatározó szerepét is hangsúlyozza. Tekintve, hogy a hálózatosodás napjainkban már minden területen megjelenő trend, a hálózatok múködését és jellemzőit sokféle diszciplína kutatja. Ezek egyetértenek abban, hogy a hálózatokban van néhány jellegzetes elem: a kapcsolódási pontok, a csomópontok és a fürtök. A hálózatok csomópontjait nevezhetjük véleményvezéreknek (opinion leaders), akik megnyerésén keresztül további személyekhez juthatunk el, gyakorlatilag egy diffúziós folyamat formájában.

Rogers ezeket a személyeket nevezi az ún. change agenteknek, a változást generáló személyeknek. Ahhoz, hogy a véleményvezérek az innovációról üzeneteket terjesszenek, interperszonális kapcsolatban kell állniuk követőikkel, elérhetőnek kell lenniük, tehát jelentős társadalmi szerepet töltenek be. A change agent olyan személy, aki befolyásolja az ügyfelek innovációs döntéseit olyan irányba, amelyet kívánatosnak tart. A change agent két módon közelítheti meg az innovációt:

1. biztosítja az új ötlet elfogadását, vagy

2. próbálja lassítani a diffúziós folyamatot, és megakadályozza bizonyos innovációk elfogadását, amelyeknek nem kívánatos hatásai vannak.

A change agent és a közösség többi tagja között a kommunikációs kapcsolat elengedhetetlen bármely, a viselkedés befolyásolására törekvő program sikeréhez. A kommunikáció meghatározza a change agent és a többi személy közötti kapcsolatot. A change agent ügynök hét szerepkört tölt be az innováció bevezetésének folyamatában. Ezek:

1. a változás szükségességének kialakítása;

2. információcsere-kapcsolat létrehozása;

3. a problémák diagnosztizálása;

4. szándék létrehozása az ügyfélben a változáshoz;

5. cselekvési szándék gyakorlati megvalósítása;

6. az adoptálás stabilizálása és a folyamatosság biztosítása és

7. a kapcsolat elérése.
A véleményvezérek és a change agentek magasabb társadalmi-gazdasági státusszal rendelkeznek és sokkal innovatívabbak a követőknél, de csak abban az esetben, ha ezt a társadalmi normák is megengedik - voltaképp ez az a tulajdonság, amely meghatározza, mennyire fogja az adott véleményvezér segíteni az innovációs diffúziót. Ugyanakkor figyelembe kell venni azt is, hogy ők nemcsak innovatívak, hanem kifejezetten ellenállóak, elutasítóak is lehetnek.

A diffúziós folyamat szívét a potenciális elfogadók utánzási (imitációs) tevékenysége adja, amely során az egyén a hálózatban hozzá közelállókhoz hasonlóan elfogad egy új ötletet, egy innovációt. Abban, hogy valaki elfogadja-e az innovációt vagy sem, nagy szerepet játszik a másoktól kapott tapasztalati információ, amely szubjektív információként tovaterjed a hálózatban. ${ }^{3}$

\subsection{Kommunikációs csatornák ${ }^{1}$}

Az innovációk diffúziója Rogers szerint valójában egyéni döntések folyamataként vizsgálható. A folyamat első fázisában az egyén a kezdeti, az újítást érintő információkkal való találkozás után kialakítja alapvető vélekedéseit és megközelítését, ami végül az innováció alkalmazásának elfogadásához vagy elvetéséhez vezet. Az újítás alkalmazása melletti döntéshozatalt és az alkalmazást egy bizonyos idő után az innováció értékelése követi.

A folyamat ezen egymást követő szakaszaiban más és más kommunikációs források és csatornák kapnak főszerepet. A megfigyelések arra engednek következtetni, hogy a tömegkommunikációs csatornáknak leginkább a folyamat első részében jut fontos szerep. A potenciális alkalmazók elsősorban ezeken a csatornákon keresztül értesülnek az újítás létezéséről és az azzal kapcsolatos alapvető információkról. E szakasz után azonban megnövekszik az interperszonális kommunikációs csatornák jelentősége: az egyének leginkább az ezeken a csatornákon érkező információk alapján döntenek az adoptálás mellett vagy ellen.

A kommunikációs csatornákat aszerint is tipizálhatjuk, hogy inkább lokális, vagy inkább kozmopolita jellegűek. A kozmopolita jellegű csatornák túlnyúlnak a vizsgált közösségeken, vagy külsődlegesek hozzájuk képest és főképp a döntéshozatali folyamat kezdeti szakaszában jelentősek. A lokális csatornák elsősorban az attitűdök kialakulásakor és az alkalmazás vagy elvetés döntésekor fontosak. 
Mint látható, az interperszonális kommunikáció lényegi szerepet tölt be az adoptálás folyamatában. Az interperszonális kapcsolatok különféle kommunikációs hálózatokat hoznak létre, amelyek jellemzői befolyásolhatják a diffúzió folyamatát. Ezeket diffúziós hálózatoknak is nevezhetjük, mivel a terjedés valódi folyamata ezeken belül zajlik le. A hálózatok vizsgálatának egyik szempontja lehet, hogy a kapcsolatba lépő egyének mennyire hasonlóak egymáshoz, például társadalmi státusz, iskolai végzettség, attitűdök szempontjából. Ha az egyének sok tekintetben hasonlóak, homofíliáról, ellenkező esetben heterofíliáról beszélünk. Az interperszonális viszonyok hálózataiban általában homofil egyének közti kommunikációról beszélhetünk. Mindenki sokkal gyakrabban érintkezik hozzá hasonlókkal, és az ilyen kommunikációs viszonyokban a megértés és a hatékony információátadás esélye igen nagy. A kölcsönös megértés esélyét ugyanis lényegesen növelik a közös értékek, tapasztalatok, a hasonló társadalmi helyzet. Ezért bizonyos szempontból a diffúzió folyamatát elősegítheti a homofil kommunikáció, hiszen a tapasztalatok szerint az egyes egyének aktívan keresik a hozzájuk közel állóktól, hozzájuk hasonlóktól származó információkat, amelyek komoly befolyással bírnak saját döntésükben.

A homofília jelensége azonban gátat is szabhat a sikeres elterjedésnek, ugyanis mintegy „láthatatlan határvonalat" képezhet az információáramlásban. Mint arról már szó volt, az újítások sok esetben a társadalom felső rétegeiből gyűrúznek lefelé. A homofília jelensége azonban útját állhatja az eltérő rétegekbe tartozók kommunikációjának, így a terjedés folyamata megtorpanhat. Márpedig a megfigyelések szerint a diffúziós hálózatok általában homofil jellegúek.

Az egyének jellemezhetők aszerint is, hogy hol helyezkednek el ezekben a hálózatokban: milyen kapcsolatokkal rendelkeznek, hol és milyen szerepet töltenek be az információ közvetítésében.

Tehát ha választ akarunk kapni a kérdésre, hogy az olvasottak ellenére egy innováció hogyan jut el egyik társadalmi csoporttól a másikhoz, alaposabban meg kell figyelnünk a diffúziós hálózatok természetét és a hálózatokban résztvevők jellemzőit.

\subsection{Idö ${ }^{1}$}

A különböző empirikus kutatások tanúsága szerint egy innováció elterjedése, ha az időbeliség tényező- jét vesszük figyelembe, a legtöbb esetben a már Tarde által is megfigyelt S-görbével ábrázolható. Tehát míg a diffúziós folyamat kezdetén viszonylag kevesen válnak felhasználókká, egy idő után megnövekszik a csatlakozók száma, majd újra csökkenni kezd.

Az egyének csoportokba oszthatók aszerint, hogy milyen hamar adoptálják az újítást. A vizsgálatok tanúsága szerint ezekbe a különböző - ún. adoptációs - kategóriákba tartozók egyes társadalmi jellemzőik szerint is elkülöníthetők, ezen változók mentén is jól körülírható csoportokba tartoznak. Rogers, miután megadja az egyes csoportoknak az érintettek teljes köréhez viszonyított százalékos részarányát, ideáltípusos jellemzést ad róluk, általánosításokat fogalmaz meg arról, hogy melyek a legfontosabb különbségek a korábban és később adoptálók között.

- Azok, akik az elsők között adoptálják az innovációt, az összes alkalmazó kb. 2,5\%-át jelentik. Ők az ún. újítók. A csoport tagjaira jellemző a kockázatvállalásra való hajlandóság és a fokozottabb érdeklődés az újdonságok iránt. Épp ennek köszönhetően általában több és szélesebb körű, az adott társadalmi csoporton túlnyúló kapcsolatokkal rendelkeznek. Az újítók csoportján belül gyakori az egymás közti személyes kapcsolat és kommunikáció, még akkor is, ha az egyének földrajzilag távol laknak egymástól. Emellett általában bőséges anyagi és technikai forrásokkal, tudástőkével rendelkeznek. Az újítók csoportjának tagjai igen fontos szerepet töltenek be a diffúziós folyamatban, hisz ők azok, akik külső kapcsolataik segítségével behozzák az adott közösségbe az innovációt.

- A korai adoptálók csoportja az összes csatlakozó 13,5\%-a. Jellemző rájuk, hogy az adott társadalmi rendszer tekintélyes, véleményformáló tagjai. Ezért a potenciális adoptálók számára mintát és jelentős információforrást jelentenek.

- A csatlakozásban az első nagyobb csoport a 34\%-ot alkotó, ún. korai többség. Ennek tagjai ugyan ritkán foglalnak el véleményalkotó pozíciókat, de az adott rendszerben jól integráltak. Jellemző rájuk, hogy alaposan megfontolva és óvatosan döntenek, ezért esetükben az előző két csoporthoz képest jóval hosszabb időt vesz 
igénybe az adoptálás procedúrája. A diffúzió folyamatában igen fontos szerepet tölt be ez a csoport, hiszen ők képezik az átmenetet a korán és a viszonylag későn adoptálók közt.

- A kései többség (34\%) esetében az adoptáció már gazdasági és szociális szükségszerűségből fakad. A csoport tagjai inkább szkeptikusak és óvatosak, különböző forrásaik viszonylag szerények.

- Végül a lemaradók (16\%) következnek. Ők általában konzervatívak, gyanakvóak a változásokkal és az újításokkal szemben, forrásaik szegényesek. Gyakori jellemzőjük, hogy az adott társadalmi rendszerben kevéssé integráltak.

A korai és késői adoptálók jellemzőire vonatkozó megfigyeléseket Rogers három nagyobb dimenzióba csoportosítva foglalja össze. Eszerint a két csoport közti különbségek tetten érhetők (1) gazdasági-társadalmi státus, (2) személyes jellemzők, valamint (3) kommunikációs viselkedés terén.

Elmondható, hogy a korai adoptálók általában iskolázottabbak, magasabb társadalmi státussal és jövedelemmel rendelkeznek, valamint társadalmilag mobilabbak, mint az őket később követő társaik. A legtöbb esetben empatikusabbak, kevésbé ragaszkodnak a megszokott, hagyományos értékekhez, hitekhez, és racionálisabban gondolkodnak. A vizsgálatok szerint ezenkívül általában pozitívabban viszonyulnak a változásokhoz és a tudományhoz, kockázatkezelési képességeik jobbak, valamint ambiciózusabb személyiségek. Ha a kommunikációs kapcsolatokat és viselkedést figyeljük meg, a korai adoptálókra jellemző, hogy több interperszonális kapcsolattal, külső kapcsolattal, jobb tömegkommunikációs eszközökhöz való hozzáféréssel rendelkeznek, mint a kései adoptálók. Rogers felfigyelt arra a paradoxonra, hogy az utolsóként adoptálók csoportjába tartozók általában azok, akik a legtöbbet profitálhatnának az innovációból.

A Rogersi megfontolások szerint a különböző adoptáló csoportok tehát nemcsak szocioökonómiai helyzetük, hanem bizonyos attitúdjeik szerint is különböznek egymástól. Itt leginkább a Rogersi kompatibilitás-fogalomra kell utalnunk, amely arra figyelmeztet, hogy egy adott innováció diffúziójának sikere nagymértékben függ attól, hogy az mennyiben illeszkedik a felhasználók értékeihez, tapasztalataihoz, szükségleteihez.

Link cikke alapján kísérletet teszünk a dohányzásról való leszokás, mint innováció elterjedésnek időbeli sajátosságait a dohányzásról való leszokás példáján keresztül megvilágítani. A dohányzás tüdőrákkal való szoros kapcsolatára rávilágító tudományos bizonyítékok az 1950-es évek elején jelentek meg. Az új ismeretek megjelenését követő változások felméréséhez Link a dohányzással kapcsolatos közvélemény-kutatások adatait elemezte. Az első 1954 ben, tehát a tudományos bizonyítékok megjelenésével egy időben elvégzett felmérésekből kiderült, hogy bár a legtöbb ember hallotta a megállapításokat, csak egy kisebbség (korai adoptálók) gondolta, hogy a dohányzás a tüdőrák okozója és ez a vélekedés nem volt összefüggésben a megkérdezettek iskolai végzettségével. A dohányzás és az iskolai végzettség között nem volt erős összefüggés 1954-ben. Az ezt követő 45 év során, amikor az emberek elkezdték elfogadni azt a meggyőződést, hogy a dohányzás a tüdőrák okozója, éles különbségek alakultak ki a dohányzással kapcsolatos attitűdök és az iskolai végzettség szintje között. A magasabb iskolai végzettséggel rendelkezők gyorsabban szoktak le a dohányzásról (korai többség), mint az alacsonyabb iskolai végzettséggel rendelkezők (kései többség). Ráadásul a felsőoktatásban részt vevők kevésbé voltak hajlamosak a dohányzásra. A lemaradók között pedig nagyobb eséllyel találhatók a legalacsonyabb iskolai végzettségűek. Az innovációhoz kapcsolódó viszony erőteljesen összekapcsolódott a szocioökonómiai státusszal. ${ }^{4}$

\subsection{A diffúziót felölelő társadalmi rendszer ${ }^{1}$} A terjedési folyamatok mindig közösségen belül zajlanak. Az adott közösség struktúrája, normái számtalan módon befolyásolhatják egy újítás elterjedésének folyamatát. E hatások közül jó néhányat már bemutattunk a fentiekben. Fontos azonban megjegyezni, hogy egy közösségben az újítások elfogadása vagy elvetése melletti döntéshozatal egyéni és kollektív szinten is történhet. Rogers a döntéshozatal három típusát különbözteti meg. A döntéshozatal módja erősen befolyásolhatja az elterjedés ütemét. Választható innovációs döntés esetén az egyén önállóan dönt arról, hogy alkalmazza-e az újitást vagy sem. Természetesen a közösség normái ekkor is igen nagy hatással vannak a folyamat alakulására. Gondoljunk csak a magyarországi egészségprogramok viszonylagos sikertelenségére. A többször is megismétlődött kezdeményezések - sorra nem 
hozták meg a kívánt eredményt. Valószínú, hogy Magyarországon eddig még nem vert gyökeret az egészséget értékként kezelő egészségkultúra és ez megakadályozta a konkrét kezdeményezések elterjedését.

A Rogers által leírt döntési típusok második fajtája egy példa révén bemutatva: egy terület, város vagy megye képviselői közösen úgy döntenek, hogy bevezetnek egy, a lakosság egészségét bizonyítottan javító programot, amelyről kikérik a lakosság véleményét is, illetve azt figyelembe véve megszervezik a hatékony implementálást. A döntés demokratikusan született.

A döntést emellett hatalmi szóval egy kisebbség is hozhatja, felhasználva ehhez erejét, befolyását. Ebben az esetben az egyéneknek nincs lehetőségük arra, hogy önállóan döntsenek az adott dolog elfogadásáról vagy elvetéséről: kénytelenek úgy cselekedni, ahogy azt számukra megszabják. Az ilyen autoritatív döntések gyors és azonnali választ váltanak ki: rövid idő alatt nagymértékú elterjedésnek, vagy fordított esetben a diffúzió sikeres megakadályozásának lehetünk tanúi.

\subsection{Az innováció következményei}

Egy újítás megjelenése és elterjedése természetesen számos változással, következménnyel jár, mind az adoptáló egyénre, mind pedig az egész közösségre nézve. Rogers kiemeli e hatások tanulmányozásának fontosságát, különös tekintettel arra, hogy az innovációk elterjedésének következményei viszonylag kevéssé kutatott terület.

\section{Innováció az egészségfejlesztésben}

A fentiekben bemutatott megközelítés egy tudatos, problémaalapú folyamatot vázol fel, melyben tényekre, adatokra alapozva, szisztematikusan zajlik az innováció kialakulása, mely egy döntéshozatali folyamatként is értelmezhető, ahol az egyes állomásokon különböző információtípusok és tudásátadó mechanizmusok játszanak szerepet. Azonban sokszor nem előzik meg ilyen tudatos folyamatok az innováció kialakulását, számolni kell a nem szándékos folyamatokkal és cselekvésekkel.

Továbbá látható, ez a megközelítés valamilyen termékre vagy szolgáltatásra irányul, melyet tényekre alapozva létre lehet hozni, fejlesztés után pedig árucikként áruba bocsátható. Az egészségben történő innovációk nem minden esetben feleltethetőek meg ennek a sémának, hiszen egy újonnan kialakított egészségfejlesztési innovációról gondolkozunk, amely esetében számos „irracionális” elem figyelembe vételével jön létre és nagyon ritkán kerül „eladásra”.

Az egészségfejlesztésben a lakosság és a közösségek jólétének javításában alapvető szerepe lehet a sikeres kommunikációnak a következetes üzenetek révén. Ki kell emelni, hogy az innovációk széleskörű elterjedése, különösen az új tömegtájékoztatási csatornák révén, kedvezően befolyásolhatja az egészségtudatosságot, az egészségműveltséget és az ellátás gyakorlatát. Az egészséggel kapcsolatos hatékony üzenetek továbbítása az egészségmagatartással kapcsolatban a legtöbb egészségfejlesztési program döntő eleme. A szóban forgó teória felbecsülhetetlen értékú eszköz az egészségügyi üzenetek terjedésének megkönnyítésére egy közösségen belül.

Rogers modellje jelentősen hozzájárulhat a viselkedésváltozás megértéséhez és promóciójához, lehetővé téve a lakosság számára adekvát módon kialakítani, módosítani a fontos innovációkat, amelyek így illeszkednek egyedi kulturális igényekhez. Ide tartozhat annak felmérése is, hogy egy egészséggel kapcsolatos innovációt hogyan sikerül elfogadtatni, továbbá egyre fontosabbá válik annak vizsgálata, hogy a különböző újítások következményei hogyan befolyásolhatják a testi-lelki egészséget.

Az elmélet figyelembe vételével a viselkedésváltoztatás sikeresen támogatható új magatartás-modellek kialakításában, bizonyos rizikómagatartások visszaszorításában és az innovációk adoptálásban (a népegészségügy szempontjából nézve megelőzés és/vagy tartós viselkedésváltozás).'

Ennek lehetséges módozata lehet egy új, kívánatos magatartás megjelenítése, népszerüsítése egy célcsoportban (commencement). Különböző témák, például a testmozgás előmozdítása az egészséges életmód részeként, vagy az alacsony jövedelmű terhes nők egészségmagatartásának pozitív irányú ösztönzése, tájékoztatás nyújtása a hozzáférhető

\footnotetext{
i A cikk a viselkedésváltoztatásnak csak néhány esetét tárgyalja. A viselkedésváltoztatás tágabb, átfogóbb értelmezéséről a Vitrai, Kimmel, Mennyire változtatható jogszabályokkal az egészségmagatartás? Mitől függ és hogyan változtatható az egészségmagatartás? I. rész Egészségtudomány 2015.3. cikkből tájékozódhat az olvasó.
} 
klinikákról és a szülés előtti ellátás előnyeiről. ${ }^{3}$

A korlátozás (cessation) egy létező és nemkívánatos vagy kockázati magatartás befejezését jelenti. A megszüntetésre példa a dohányzásról való leszokásban való segítségnyújtás. Ugyanilyen fontos lehet egy nemkívánatos viselkedés prevenciója a viselkedésváltoztatás megkönnyítésében. ${ }^{3}$

A bemutatott teória hatékonyan alkalmazható a fent említett viselkedésmegváltoztatásra törekvő egészségfejlesztési programokban. Például egy innováció célközönségének osztályozása az adoptáció kategóriái szerint segíthet a diffúzió hatékonyságának maximalizálásában azáltal, hogy a viselkedésváltoztatás folyamata kezdetben az innovátorokra fókuszál. Egy ilyen stratégia növelhetné a change agentek számát és javíthatná a sikeres diffúzió lehetőségét a célcsoportban. Továbbá az innováció erősségeinek és gyengeségeinek azonosítása, felhasználva az újítások korábban bemutatott öt fő kategóriáját (viszonylagos előny, kompatibilitás, összetettség, kipróbálhatóság és megfigyelhetőség) rendkívül előnyös lehet az üzenet megtervezésében és megvalósításában egy népegészségügyi kampány során. Az innováció terjesztése oly módon, hogy hangsúlyozzák az előnyöket és a negatív következmények szerepét csökkentik, jelentősen növelhetik az innovatív népegészségügyi programok elfogadottságát és hatékonyságát.

Egy másik szempont, amely miatt különösen hasznos lehet a rogersi elmélet a népegészségügyben, az a társadalmi normák, azaz az értékek és az elfogadott társadalmi gyakorlatok azonosítása a célzott közösségben. Például egy közösség kulturális és vallási alapértékeinek azonosítása, amelyek esetleg ellentétesek az egészségügyi innovációval, kulcsfontosságú az innováció hatékonysága szempontjából, mivel ezek a tényezők elkerülhetetlenül befolyásolják az innováció-döntési folyamatot.

Az egészségügyi programok tervezőinek azonosítaniuk kell ezeket a potenciális akadályokat, mielőtt az innovációt a célközösség körében bevezetik. A kialakított normák megértése lehetővé teszi a tervező számára, hogy elkerülje a diffúziós folyamat buktatóit. Kiemelve egy adott innováció előnyeit és gondoskodni arról, hogy a közösség társadalmi normáival összhangba kerüljön, nagymértékben javíthat a diffúzió mértékén és az innováció elfogadásán. A népegészségügy területén az innovációk következményei jelentős hatással vannak a közösségek és az egyén jólétére. A következmények olyan változásokat jelentenek, amelyek az egyén vagy a társadalom szintjén következhetnek be az adott innováció elfogadása vagy elutasítása miatt, pl. a népesség jóllétében.

A következmények lehetnek kívánatosak illetve nem kívánatosak, közvetlenek vagy közvetettek, előre láthatóak és váratlanok. Az újítás és a diffúzió egy innováció adoptálásának következményei.

Az innovációk hatását illusztrálhatjuk egy példán keresztül, az integrált kártevő-gazdálkodás (IPM) elfogadása a kaliforniai paradicsomtermelők körében. Ebben az esetben az IPM adoptálói alkalmaztak egy korábbi innovációt, amelyet módosítottak a saját helyzetüknek megfelelően. Így, bár egy meglehetősen bonyolult folyamat volt, amely sok időt és folyamatos erőfeszítést igényelt, tükrözi az előnyös újításokban rejlő hatalmas lehetőségeket, hiszen amikor a mezőgazdasági termelők elfogadták, hogy elegendő kevesebb peszticidet alkalmazniuk a paradicsom termesztésekor, a földeken dolgozó mezőgazdasági munkások egészsége javult.

\section{Az innovációk diffúziója az egészségegyen- lőtlenségekben}

Az innovációk egyenlőtlen diffúziójának az a következménye, hogy elsősorban a magasabb szocioökonómiai pozíciójúak képesek arra, hogy korábban

alkalmazzanak új magatartásformákat, amelyeket az alacsony státuszúak csak később képesek követni. Az elmélet elfogadható magyarázattal szolgálhat az egészségegyenlőtlenségekben bekövetkező növekedésre, illetve azok tartós fennmaradására. Segít megérteni azokat a periódusokat, amikor a magatartásváltoztatás eredményeként nagyobb javulás lép fel a népesség körében. A fejlett országok az epidemiológiai fejlődés abban a szakaszában vannak, amelyben a civilizációs betegségek (kardiovaszkuláris betegségek, bizonyos rákos megbetegedések, amelyek az előző szakaszban dominálták, gyorsan visszaszorulnak. Ez a javulás gyakran valamilyen innovációra, illetve annak adoptálására vezethető vissza. Például részben az egészségügyi ellátás fejlődése, másrészről a magatartás változtatás eredményeként értelmezhető (dohányzásról való leszokás, egészségesebb táplálkozás), ugyanis a jobb státuszúak korábban alkalmazzák az új 
magatartásformákat.

Befejezésül úgy összegezhetünk, hogy az elmélet hozzájárulhat hatékony népegészségügyi-egészség- fejlesztési programok kidolgozásához, azok közösségi igényekhez való igazításához, megvalósításához, amely által a hazai lakosság egészségi állapota javulhat.

\section{HIVATKOZÁSOK}

${ }^{1}$ Dessewffy, Tibor, Galácz, Anna (2002): Mobilkommunikáció és Társadalmi Diffúzió. Mobilközösség - mobilmegismerés 233-248. szerk. Nyíri Kristóf Budapest: MTA Filozófiai Kutató Intézet.

${ }^{2}$ Gerdesics, Viktória, Pavluska, Valéria (2013): Irodalomkutatás az innováció elfogadás-elméletekről. Pécsi Tudományegyetem. Pécs

${ }^{3}$ Haider,Muhiuddin, Kreps Gary L (2004) Forty Years of Diffusion of Innovations: Utility and Value in Public Health, Journal of Health Communication: International Perspectives, 9:S1, 3-11, DOI: 10.1080/10810730490271430

${ }^{4}$ Link, Bruce G. (2008). Epidemiological Sociology and the Social Shaping of Population Health. Journal of Health and Social Behavior 49:367-84. 